\title{
GENETIC RESOURCES OF PERENNIAL FORAGE GRASSES IN SERBIA: CURRENT STATE, BROADENING AND EVALUATION**
}

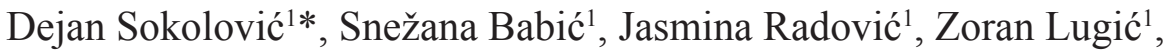 \\ Aleksandar Simić2 , Vladimir Zornić ${ }^{1}$, Mirjana Petrović ${ }^{1}$
}

\begin{abstract}
Due to historical background of vegetation development, geographical position, climate and relief, Serbia represents one of the 158 world biodiversity centres, based upon the number of plant species and territory size (biodiversity index 0.72). Large areas in Serbia are under natural grasslands and pastures, composed of forage grass species, and important as source of natural plant genetic diversity and germplasm for breeding. These eco-systems represent basic prerequisites for sustainable forage production, but very low potential of them is utilized and genetic resources are not protected. Family Poaceae is present in Serbia flora with 70 genera and among them from the aspect of forage production and quality, the most important are perennial Festuca, Lolium, Dactylis, Phleum, Bromus, Arrhenatherum, Poa and Agrostis species. Most of these grasses have been bred in Serbia and lot of cultivars were released. These cultivars contain autochthonous Serbian material and represent great and important resource of genetic variability. Therefore, collecting of new samples which are acclimatised to local eco-geographical conditions and including them in plant ex situ gene bank is of exceptional importance for further utilization in different plant breeding programmes as well as genetic resources protection. These autochthonous populations have natural variability and very often have satisfactory yielding performance in comparison with introduced cultivars, which referred them for direct phenotypic selection for cultivars release. Broadening of forage grasses genotypes collection is permanent objective of Serbian scientists. Collected accessions are being characterized and evaluated for important phenological, morphological and agronomical traits. In this paper genetic resources of forage grass species, their diversity and potentials, state of the grasses gene banks, as well as possibility for breeding of new cultivars has been analysed.

Key words: Fodder grasses, ex situ gene bank collections, accessions, characterisation, evaluation, variability

Review Paper (Pregledni rad)

Sokolović D, Babić S, Radović J, Lugić L, Zornić V, Petrović M, Institute for forage crops, Kruševac

${ }^{2}$ Simić A, Belgrade University, Faculty of Agriculture, Zemun-Belgrade

*e-mail: dejan.sokolovic@ikbks.com

*** Rad je usmeno izložen na skupu “Genetički resursi u poljoprivredi i šumarstvu”, 1.11.2017. u Beogradu, u organizaciji Академије инжењерских наука Србије - АИНС, www.ains.rs
\end{abstract}




\section{Introduction}

From ancient times till today humankind history has been closely connected with grasses and grasslands. Civilisations were developed just on grasslands and disappeared with grassland destruction. Grasslands are essential for prehistoric people gatherers and hunters. A couple of dozen of grass species have been used for millennia since the time of nomadic people found a way to domesticate ruminants and horses. In addition to the nutrition of domestic animals, they are also immeasurably significant for the preservation of soil and water quality. Moreover, perennial grasses nowadays make a very important part of the urban landscape, and above all, the philosophy of life in much of the modern world. Consequently, production of grass seed and its market become very significant in the world and Serbia, as well (Đokić et al., 2013).

Total plant biodiversity within Serbian borders is significant. Due to geographic position Serbia is part of broader Mediterranean area, one of the largest centre of origin and divergence of many cultivated plant species important for agriculture, especially forage plants. Serbia represents one of the 158 world biodiversity centres (biodiversity index of 0.72), based upon the total number of plant species (including mosses) and territory size. On Serbian territory lives $40 \%$ of all plant species present today in total European flora (Stevanović et al., 2000). The main factors of such floral diversity are historical background of vegetation development, geographical position, climate, relief, presence of streams. According to recent estimations, the flora of Serbia contains 3662 taxa, i.e. 3272 species and 390 subspecies, (Kišgeci and Cvetković, 1998), showing very high floristic diversity and density per unit area compared to other European countries. Considering the vegetation diversity of Serbia, about 600 to 1200 plant communities have been identified (Lakušić, 2005), including forests, steppes, meadows, pastures, vegetation of sand dunes and saline soils, swamps, alpine tundra, etc. Among them, after detail analysis, 273 meadow and pasture communities were determined and included in 46 vegetation alliances from 24 orders and 10 classes of grasslands (Kojić et al., 2004).

\section{Diversity of genetic resources of forage grasses and grasslands in Serbia}

Perennial grasses and their associations are, as we recognise them today, product of several hundred thousand years long natural evolution and selection for adaptability and persistency in constantly changing environment. This natural selection was additionally amplify with selection pressure of grazing animals and finalised with few dozen of centuries long period with human influence. All that resulted in huge biodiversity and adaptability to different environments of perennial grasses and their associations, grasslands.

Grasses belong to the family which comprise of ecologically dominant plant species, covering waste areas of land and represents most widespread family of plants in the world. Number of species in the family Poaceae is still variable depending on the author or literature source, but it is certain that is among the most numerous families in plants. It consists of more then 10.000 species (from 7500 to 11.000), classified in 650 to 785 genus, 25 do 50 tribes and up to 12 (312) subfamilies (Moser and Nelson, 2003; Gibson, 2009). Grasses reached that level of biodiversity within grassland associations which represent their natural habitats and communities. Therefore when we are talking about grasses taxonomy and biodiversity, we 
have to consider grassland sintaxonomy and diversity of their composition.

Total agricultural land in Serbia cover 5.093.000 ha with 1.454 .000 ha of permanent natural grasslands (Statistical Office of the Republic of Serbia, 2009) especially in hillymountainous area. Natural features, diverse relief and climatic diversity result in great wealth of grassland plant species (including many endemic plants). The most diverse vegetation classes are Festuco-Brometea (Br.Bl. et R. TX. 1943) with 1194 plant species (41.8\% of all plant species in Serbia) and Molinio-Arrhenateretea (R. Tx. 1937) with 895 species included (Lakušić, 2005). Most of plant species forming these grassland communities belong to family Poaceae, with 70 genera of which, from the aspect of agriculture and production, the most interesting are Festuca with 21 species, Lolium with 5 species, Dactylis with 3 species, Bromus with 14 species, Poa with 17 species, Phleum with 8 species and Agrostis with 6 species. Many of them contain numerous sub-species, varieties and forms. Grassland generally represents basic prerequisites for sustainable forage production, but very low potential of these eco-systems is utilized today. The possibility of their enhanced utilization requires serious work, but also due to large species diversity and their complex relationships, those ecosystems are extremely vulnerable and should be protected.

\section{Main categories of grasses genetic resources}

There are four main categories of genetic resources of perennial grasses: wild relatives of domesticated grass species (from the same genus), wild of semi natural forms of domesticated grass species (autochthonous or wild populations), „landraces” (ecotypes or domesticated populations which are acclimatised on specific region or locality, like farms where they are used) and bred cultivars.

\section{State of diversity of natural autochthonous populations and wild relative species}

Serbian grasslands represents rich fund of autochthonous plant genetic resources of forage grasses (Sokolović et al., 2009), since most of species have wild populations and relatives in the nature which show high degree of genetic variability and specificity usable in breeding (Sokolović et al., 2007; Babić et al., 2009). Very often they have satisfactory yielding performance in comparison with introduced cultivars (Sokolović et al., 2003a; 2004a; 2010b), and can be used for direct phenotypic selection for cultivars developing. They are especially present in marginal areas which are not used for intensive agriculture and on natural grasslands on uplands of Serbia.

The most valuable native grass genetic resources, components of Serbian natural grasslands are especially from genus Festuca, Lolium, Dactilys, Agrostis and Poa. Meadow fescue (Festuca pratensis Huds.), orchardgrass (Dactylis glomerata L.) and perennial ryegrass (Lolium perenne L.) are very important perennial fodder grasses with multiple purposes for animal feed production on grasslands and pastures. They are caenobionts of plant associations from the class MolinioArrhenatheretae, from lowlands to valleys in hilly areas. Festuca pratensis Huds. is mostly frequent in associations Cynosuretum cristati, Festucetum pratensis and anthropogenic association Arrhenatheretum elatioris, where edificatory species is tall oatgrass, also very important for fodder use. Dactylis glomerata L. is characteristic species of grasslands from alliance Arrhenatherion elatioris with different presence and covering. Perennial ryegrass, 
as most important fodder grass in Europe, in Serbia is dominantly present in association Lolio-Cynosuretum cristati, especially on places treated upon intensively (Sokolović et al., 2003b). Agrostietum and Poetum associations are also very present and well adapted on hilly and mountainous regions and represent very important natural grasslands for animal nutrition (Kojić et al., 2005; Vučković et al., 2007) and they are very rich in grasses natural genotypes.

All those valuable associations and grass species should be protected as very vulnerable genetic resources within their natural habitats. Although significant efforts in protection of natural resources (especially in meadows and pastures) has been made in Serbia, a great number of plant associations and species as their components are still endangered by human unpredicted activities or inappropriate agriculture management.

\section{Diversity of cultivars of fodder grass species}

Total number of plants species used in Serbian commercial agricultural production without flowers is 233 , while as field crops 185 species are used. Among them only few species of perennial forage grasses have been bred and used on sown grassland or filed production.

The most important perennial grasses species used as fodder crops in Serbian agriculture and breeding are orchardgrass (Dactylis glomerata L.), Italian ryegrass (Lolium multiflorum Lam.), meadow fescue (Festuca pratensis Huds.), perennial ryegrass (Lolium perenne L.), red fescue (Festuca rubra L.), timothy (Phleum pratense L.), tall oatgrass (Arrhenatherum elatius (L.) P. Beauv. ex J. Presl \& C. Presl.), tall fescue (Festuca arundinacea Schreb.) and smooth brome (Bromus inermis Leyss.). Some of mentioned species are characterized by high number of intra-species taxa, such as subspecies, varieties and forms. All those plant species have been using as forage very long time and they have been improved by breeding many times for better utilization (Tab. 1).

Table 1. Number of created and active varieties of fodder grasses in Serbia

Tabela 1. Broj ukupno registrovanih i trenutno gajenih sorti krmnih trava u Srbiji

\begin{tabular}{|c|c|c|c|c|c|}
\hline \multicolumn{6}{|c|}{ Perennial grasses } \\
\hline Species & Total & Active & Species & Total & Active \\
\hline Cocksfoot & 6 & 3 & Tall oatgrass & 3 & 1 \\
\hline Perennial ryegrass & 2 & 1 & Tall fescue & 3 & 1 \\
\hline Italian ryegrass & 3 & 2 & Red fescue & 2 & 1 \\
\hline Timothy & 2 & 1 & Meadow fescue & 1 & 1 \\
\hline \multirow[t]{2}{*}{ Smooth brome } & 1 & 1 & Meadow foxtail & \multicolumn{2}{|c|}{ In the state trial now } \\
\hline & \multicolumn{3}{|c|}{ Total } & 23 & 12 \\
\hline
\end{tabular}


It is noticeable that number of registered cultivars is not extremely high like cereals or maize, but great value of these cultivars lies in genes, because in this list there are old, primal varieties and breeding populations, landraces, indigenous material, etc. Also, most of created cultivars contain autochthonous wild genotypes and genotypes from old adapted cultivars from abroad and represent great and important resource of genetic variability. However, there is a danger of genetic erosion of these resources caused by gradual introduction of modern highyielding cultivars which can be productive in first two years of grassland utilization but subsequently lose primacy regarding to great drought susceptibility.

\section{Perennial forage grasses PGR conservation in Serbia}

Two models of conservation are possible for grasses genetic resources. First is for autochthonous populations, ecotypes, landraces or cultivars which can be maintained in situ (for landraces or cultivars it can be referred to as "on farm"). Second is dominant and represents maintaining of seed or vegetative samples in ex situ gene banks.

The main objective of in situ conservation is to maintain the environment which has led to development of the distinctive properties of the genetic resources. In situ conservation allows that genetic evolution and specific environment, which developed such unique genetic resource, continue influence on further development of forage plants. During the past few decades, the protection of fodder crops in situ has received increasing interest over Europe (Boller and Greene, 2010), especially in grassland dominated regions which are centres of diversity. This type of PGR protection is not developed in Serbia because it is complicated and expensive to organize and maintain. Nevertheless, it is necessary and quite possible to manage in uplands of Serbia, to protect and conserve various types of natural grassland from their degradation or destruction by inadequate grassland management or uncontrolled production of other cultures (potato or raspberry). This kind of PGR protection is achievable by contracting between state and grassland owners (farmers) on long time scale, for preserve traditional grassland management and production.

It can be claimed that within perennial grasses genotypes some of them are in some kind of in situ protection. Serbian old domestic varieties and old landraces have been grown in lot of farms, utilized and multiplied by nonintensive management representing in fact in situ PGR protection.

By ex situ conservation, genetic structure of the original seed sample is preserving. The crucial is that all actions concerning ex situ management like collecting, storage, regeneration or distribution is aimed to keep presence and frequency of alleles within the population as constant as possible. As well as this type of PGR preservation is an important tool for conserving genetic diversity, it is also powerful tool to provide genetic resources for a broad range of users (Greene and Morris, 2001). The most important and the most common way of utilisation of ex situ PGR accessions is breeding (Ghesquiere and Beart, 2012).

\section{The state of perennial grasses ex situ collection in Serbia National PGB collection}

The aim of the formation of National plant gene bank is to ensure equal treatment, conservation and utilization of genetic resources in the state, as well as to ensure the adequate national policy in this field. Today in Serbian plant gene bank, which is officially active from 
2015, are ex situ stored more than 4.000 seed accessions of agricultural and autochthonous plant species. Majority of accessions in this collection belong to the economically most significant cultivated species (maize, wheat, sunflower, barley) and their old lines, hybrids, varieties and populations. However, from the aspect of genetic diversity in our region, many species were not adequately represented in
Gene bank (medicinal and aromatic plants, textile plants, forage plants, some vegetable species, and a series of wild relatives of the species).

National collection of perennial grasses is consisted of 124 samples (Tomić et al., 2010), dominantly wild populations (Tab. 2).

Table 2. Collection of forage grasses in Gene Bank of Serbia Tabela 2. Kolekcija krmnih trava u Biljnoj banci gena Srbije

\begin{tabular}{lclc}
\hline \multicolumn{1}{c}{ Species } & No of samples & \multicolumn{1}{c}{ Species } & No of samples \\
\hline Dactylis glomerata & 12 & Agrostis stolonifera & 34 \\
Festuca arundinacea & 5 & Agrostis gigantea & 15 \\
Festuca pratensis & 3 & Agrostis capilaris & 35 \\
Festuca rubra & 2 & Lolium perenne & 10 \\
Phleum pratense & 4 & Lolium multiflorum & 4 \\
\hline
\end{tabular}

Collection storage conditions should be optimized to maximize longevity, since seed regeneration is the most expensive activity of germplasm ex situ management. Ex situ conservation of forages usually involves the storage of seed in gene banks in standard temperatures of $0-4{ }^{\circ} \mathrm{C}$ for active collections and $-18{ }^{\circ} \mathrm{C}$ for base collections, both at low seed moisture (3-7\%). Durability of seed storage is influenced by seed condition and initial germination. If seed plants are grown and harvested under optimal conditions and initial germination was $>95 \%$, duration of storage for many forage species is predicted to be 100 years or longer when stored at $-18{ }^{\circ} \mathrm{C}$ (Sackville-Hamilton et al., 1998).

However, all grass accessions in Serbian ex situ PGB is today stored in a cold chamber at $+4{ }^{\circ} \mathrm{C}$ and approximately $50 \%$ relative air humidity. Periodically, seed accessions have to be regenerated and multiply when seed amount or viability drops below threshold limits or newly collected seeds need to be increased for distribution. Careful consideration needs to be given to regeneration to minimize any genetic change during the process, especially in forage grasses, since they are largely out crossers and genetically heterogeneous. From 1996 when accessions of perennial grasses were entered in PGB, they were regenerated fully ones, in 1999 in Institute for forage crops and partly, half of the collection with the critical germination (below 50\%), in 2009 and 2010 also on the field of the Institute for forage crops in Globoder, Kruševac (Pic. 1 and 2.). 

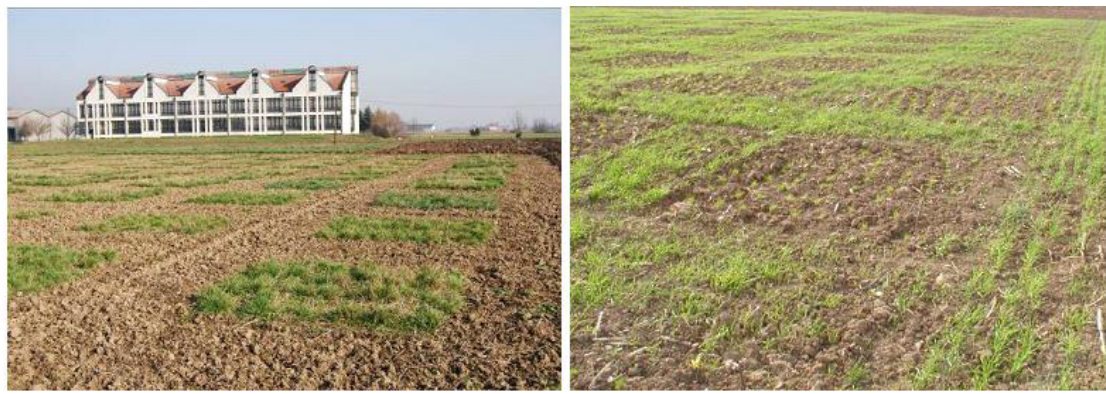

Picture 1. Pollination isolation plots for grass seed regeneration before and after sowing of isolators Slika 1. Izolacione parcele za umnožavanje uzoraka trava, pre i posle setve izolacionog useva

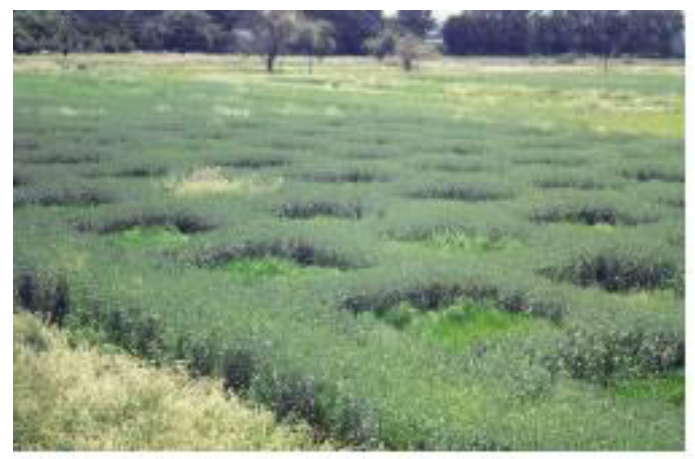

Picture 2. Pollination isolation plots for grass seed regeneration with barley as isolator crop Slika 2. Parcele za umnožavanje uzoraka trava sa ječmom, kao izolacionim usevom

Plants were sown in isolation of cereals (barley and oat) in plots of $4 \mathrm{~m}^{2}$ with 100 plants per plot. Plots were separated by $2 \mathrm{~m}$ of isolator crop on each side and with different species in next plots. Therefore, accessions of the same species were at least $6 \mathrm{~m}$ apart.

In recent years number of accessions in National PGB for forage grasses has not been changed significantly. Nevertheless, some accessions were collected through regional project realized within SEEDNet with name "Regional collecting expedition and ex situ conservation of Trifolium pratense L., Medicago falcata L., Dactylis glomerata L. and Festuca pratensis Huds.”. Several expeditions were organized (Rtanj, Fruška gora, Kopaonik, Pešter, Tara, Vlasina) and some of grass seed samples were collected (Tab. 3) (Sokolović et al., 2012a). 
Sokolović D. et al.

Table 3. Number of collected perennial grasses accessions in regional SEEDNet project Tabela 3. Broj prikupljenih uzoraka višegodišnjih trava u Regionalnom SEEDNet projektu

\begin{tabular}{lclc}
\hline Collected species & No. of accessions & Collected species & No. of accessions \\
\hline Dactylis glomerata & 20 & Festuca pratensis & 17 \\
\hline
\end{tabular}

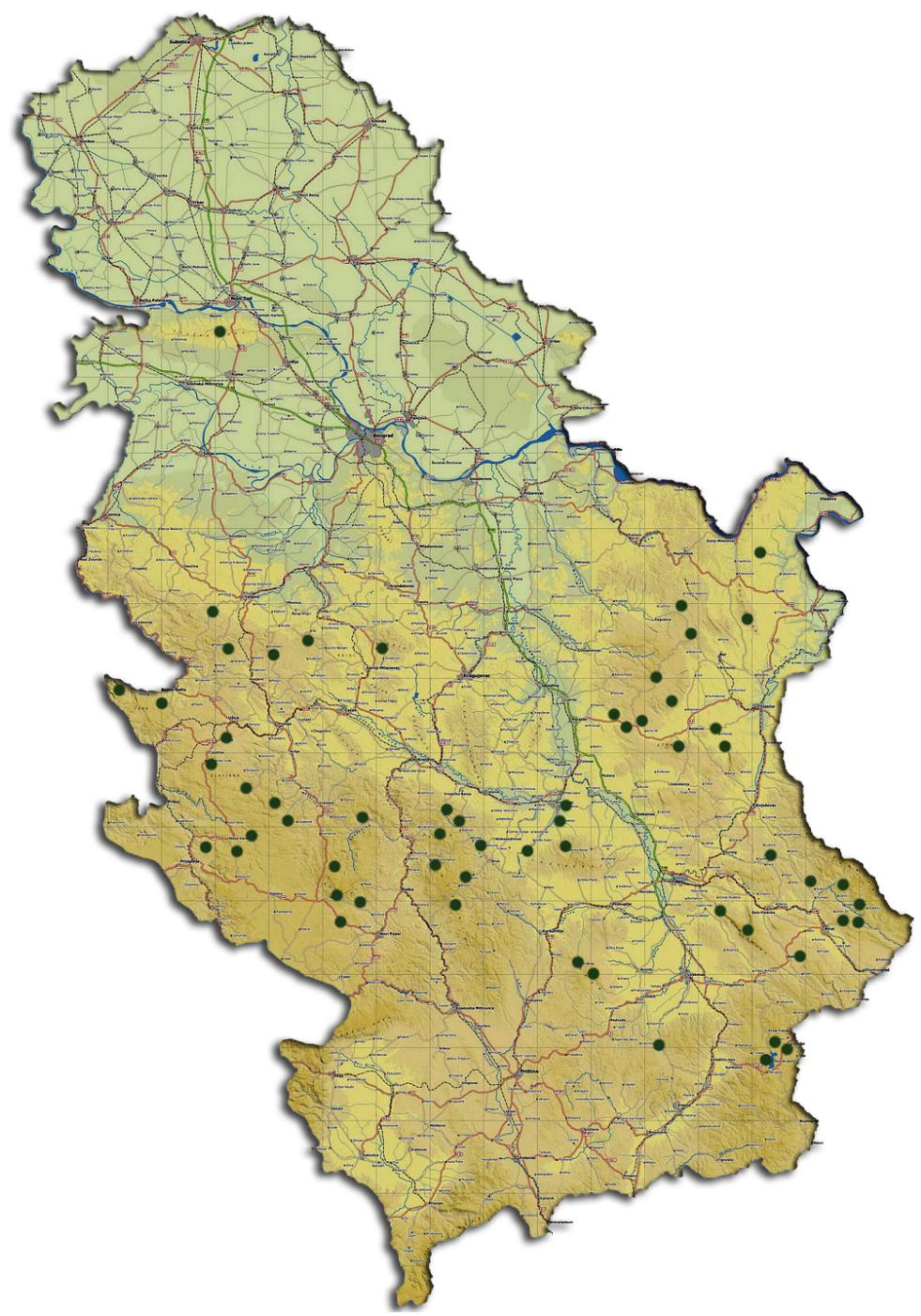

Picture 3. Distribution of localities on the map

Slika 3. Raspored lokaliteta na karti 


\section{Collection in Institute for forage crops}

In contrast to the National PGB, collections of perennial grasses in breeding Institutes and companies have been improving regularly, dominantly for breeding purposes (Sokolović et al., 2010b; 2011b), since autochthonous material exhibits a desirable level of adaptability to local agro-ecological conditions and persistency (Babić et al., 2010; Sokolović et al., 2004b; 2010a; 2011a) or drought tolerance adaptations (Sokolović et al., 2012b). Currently, collecting has been performing in Institute for forage crops as unique perennial grasses breeding company in Serbia, but it is still permanent objective of all Serbian scientists who are engaged in grass genetic resources, as well.

Lot of expeditions (more than 20) were conducted in recent years and perennial grasses collection was enlarged primarily with seed samples of autochthonous populations (Sokolović et al., 2009; 2012a), but also with collected green plants. Collecting was performed every year from $01^{\text {st }}$ to $20^{\text {th }}$ August in phase of full seed ripening. Chosen localities and populations have been characterized regularly with large species covering and presence. Seed was gathered from at least 20 randomly chosen plants in diameter of $50 \mathrm{~m}$ representing average population sample. All accessions were chosen regarding some unique or desirable trait for breeding. Meadow fescue was collected from various habitats with focus to resistance on stressful environment conditions and persistency, whereas late and medium maturing and robust habitus were favourable traits for orchardgrass. Perennial ryegrass was collected from extreme habitats showing high accessions adaptability to droughty conditions (field roads, road banks or field edges). Tall fescue populations were chosen by soft and smooth leaves and meadow foxtail by higher position of leaves on steam, both in order to achieve better DM quality.

Lot of places in Serbia were investigated, mainly on high altitudes, in East Serbia (Rtanj, Tupižnica, Južni Kučaj, Homoljske planine, Resava, Miroč), Central Serbia (Kopaonik, Željin, Goč, Jastrebac, Golija, Pešter plateau, Sjenica basin, Javor, Radan), West Serbia (Tara, Zlatibor, Rudnik, Suvobor, Maljen, Povlen, Zlatar, Jadovnik, Mučanj), South Serbia (Vlasina, Stara planina, Suva planina) and Fruška Gora in North Serbia with more than 80 localities in total. Position of localities is presented on Picture 3 . and it is noticeable on map that most of them are well distributed all over hilly-mountinous regions of Serbia which are not being used in intensive agriculture and which represents most important centres of perennial grasses biodiversity in Serbia. Therefore nowadays there are 230 grass samples in total in collection of the Institute for forage crops in Kruševac (Tab. 4.) All these accessions are characterised by some unique and promising trait for breeding of mostly forage cultivars, but also for creating of turf type cultivars or cultivars for special purposes. Generally, natural populations demonstrate great adaptability to different macro and micro habitats varying in traits of adaptive significance and very often can be used for direct phenotypic selection and for cultivars release.

\section{Evaluation of forage PGR accessions}

To make ex situ collection accessions useful to potential users, especially breeders, seed accessions need to be characterized and evaluated and this information need to be completely available to potential users. Generally, characterization focuses on simply inherited traits, while evaluation is mainly directed to quantitative traits. 
Table 4. Collection of perennial grasses autochthonous populations in the Institute of forage crops, Kruševac Tabela 4. Kolekcija višegodišnjih autohtonih populacija trava u Institutu za krmno bilje u Kruševcu

\begin{tabular}{lclc}
\hline Species & No. of accessions & Species & No. of accessions \\
\hline Festuca pratensis & 40 & Festuca rubra & 6 \\
Arrhenatherum elatius & 25 & Bromus inermis & 8 \\
Festuca arundinacea & 10 & Alopecurus pratensis & 8 \\
Dactylis glomerata & 103 & Lolium multiflorum & 3 \\
Phleum pratense & 14 & Lolium perenne & 13 \\
\hline Total & & 230 & \\
\hline
\end{tabular}

International Descriptor Lists have been published for forage grasses in 1985 (https:// www.bioversityinternational.org/e-library/ publications/descriptors/). This provides a starting point for characterizing accessions in a standard format. Unfortunately the cost of germplasm evaluation is high, particularly for forage grasses which generally exhibit large genotype by environment interactions due to their out crossing nature. Another difficulty is appearing if evaluation is made in real production conditions in swards. This rise total cost of evaluation due to traits evaluated (interplant competition, persistence and sward growth pattern, grazing tolerance and yield).

Most of samples which are collected in Serbia have already been characterized in details and evaluated for important phenological, morphological and agronomical traits, mainly for breeding purposes (Babić et al., 2009; Sokolović et al., 2004a). Great level of variability within and among genotypes was detected for all investigated traits which are chosen according importance for every grass species individually.

\section{Conclusion}

Based on long lasting investigation of genetic resources of perennial forage grasses it can be concluded that region of Serbia is extremely rich with all species with high degree of intra-species and population variability.
This fact allows collecting of huge number of accessions and breeding and selection of best genotypes for different purposes, from fodder use (grazing, hay making and ensiling) to special use (turfs, erosion protection, etc). Based on many expeditions conducted recent years across Serbia, large gene pool of perennial grasses was formed with high amount of collected material ( 230 accessions). The most important areas for collecting are hilly-mountainous regions of East and Central Serbia which hasn't been used for intensive agriculture and represent most important centres of perennial grasses biodiversity in Serbia. Most of collected accessions are already characterised and evaluated. Lot of their genotypes show excellent traits for fodder production, but also good special characteristics for alternative usage of perennial grasses (turf and amenity use, erosion protection and orchards and degraded land greening etc). Collected material is very stable base for breeding in future years in Serbia and for enlarging of National collection of perennial grasses in Gene bank of Serbia

\section{References}

Babić S, Sokolović D, Anđelković S, Štrbanović R, Živković B (2009): Variability of the most important traits of timothy (Phleum pratense L.) autochthonous populations. Book of 
abstracts IV Congress of the Serbian Genetic Society, Tara, 245.

Babić S, Sokolović D, Radović J, Anđelković B, Živković B (2010): Varijabilnost najvažnijih osobina autohtonih populacija lisičjeg repa (Alopecurus pratensis L.) i bezosnog vlasena (Bromus inermis Leyss.). Zbornik radova $X V$ savetovanja o biotehnologiji, Čačak, 15 (16): 129-134.

CGIAR Research Centre: Research for development in agricultural and tree, Descriptors. https://www. bioversityinternational.org/e-library/ publications/descriptors/

Boller B, Greene SL (2010): Genetic Resources, p.13-37. In B. Boller, Posselt U.K., Veronesi F. (eds.), Fodder Crops and Amenity Grasses. Handbook of Plant Breeding 5, Springer Science+Business Media, NY, USA.

Đokić D., Terzić D., Milenković J., Dinić B., Anđelković B., Stanisavljević R., Barać S. (2013): Značaj i stanje semenarstva krmnih biljaka u poljoprivredi Republike Srbije. Selekcija i semenarstvo, Vol. XIX (2): 11-25.

Ghesquiere A i Beart J (2012): The use of Genebank accessions in the breeding programme of Lolium perenne, Ch 39, 295-299. In: S. Barth and Melbourne D. (eds.) Breeding Strategies for Sustainable Forage and Turf Grass Improvement, Springer.

Gibson DJ (2009): Grasses and Grassland Ecology. New York: OUP Oxford.

Greene SL, Morris JB (2001): The case for multiple-use plant germplasm collections and a strategy for implementation. Crop Sci. 41: 886-892.

Kišgeci J, Cvetković M (1998): The National Programme for Plant Genetic Resource of the F.R. Yugoslavia. Proceeding of the European Symposium: Implementation of the Global Plan of Action in Europe - Conservation and Sustainable Utilization of Plant Genetic resources for Food and Agriculture, 30 June - 3 July, Germany, 361.

Kojić M, Mrfat-Vukelić S, Dajić Z, DjordjevićMilošević S (2004): Meadows and pastures of Serbia. Institute for agricultural research 'Serbia', Belgrade. (in Serbian).

Kojić M, Mrfat-Vukelić S, DjordjevićMilošević S (2005): Basic phytochenological and economical characteristics of natural meadows and pastures of Serbia. Biotechnology in animal husbandry, 21(5-6): 187-191.

Lakušić D (2005): Relation between species and ecosystem diversity. In: Biodiversity at the onset of the new millennium (ed. M. Andjelković), SANU, Belgrade, 75102.

Moser LE, Nelson CJ (2003): Structure and Morphology of grasses, p.25-50. In: Barnes et al. (eds), Forages - An introduction to grassland agriculture, Iowa State Press, USA.

Sackville Hamilton NR, Chorlton KH, Thomas ID (1998): Appendix III. Guidelines for the regeneration of accessions in seed collections of the main perennial forage grasses and legumes of temperate grasslands. In: L.P. Maggioni, et al. (eds.) Report of a working group on forages. Sixth meeting, 6-8 March 1997, Beitostølen, Norway. International Plant Genetic resources Institute, Rome, 167-183.

Sokolović D, Tomić Z, Lugić Z (2003a): Dry matter yield components of perennial ryegrass (Lolium perenne 
L.) populations. Grasslands science in Europe, 8: 126-130.

Sokolović D, Tomić Z, Mrfat-Vukelić S, Radović J (2003b): Current state of Lolium perenne L. and Dactylis glomerata L. collections in Serbia. Czech J. Genet. Plant Breed., 39: 256259.

Sokolović D, Radović J. Ignjatović S (2004a): Study of morphological traits and yield of tall oatgrass population from Serbia. Grasslands Science in Europe, 9: 437439.

Sokolović D, Ignjatović S, Tomić Z (2004b): Prinos i kvalitet krme eksperimentalnih genotipova višegodišnjih trava. Acta Ariculturae Serbica, Vol. IX, 17: 135142.

Sokolović D, Radović J, Lugić Z, Tomić Z, Babić S (2007): Genetic variability of perennial ryegrass (Lolium perenne L.) autochthonous populations collected in Serbia for seed yield and seed yield components. Proceedings of EUCARPIA fodder crops and amenity grasses section and Medicago spp. Group joint Meeting, Perugia, Italy, 253-256.

Sokolović D, Babić S, Tomić Z, Radović J, Lugić Z, Cvetković M (2009): Broadening of perennial ryegrass (Lolium perenne L.) and cocksfoot (Dactylis glomerata L.) autochthonous genotypes collection. Book of abstracts of the IV Congress of the Serbian Genetic Society, Tara, Jun, 1 st -5 th, p. 177.

Sokolović D, Babić S, Marković J, Radović J, Živković B, Simić A (2010a): Dry matter production and nutritive value of perennial ryegrass cultivars collection, Ch 48, 341-346. In: C. Huyghe (ed.) Sustainable Use of Genetic Diversity in
Forage and Turf Breeding, Springer.

Sokolović D, Tomić Z, Babić S (2010b): Perennial forage grasses breeding in Serbia: achievements, limits and prospects. XII International Symposium on Forage Crops of Republic of Serbia, 26-28 May, Kruševac-Serbia, Biotechnology in Animal Husbandry, 26 (Spec. issue) (1): 91-106.

Sokolović D, Lugić Z, Radović J, Živanović T, Babić S, Simić A, Maletić R (2011a): Evaluation of morphological traits, dry matter yield and quality of Lolium perenne L. autochthonous populations from Serbia through multivariate analysis. Genetika, 43 (1): 129-140.

Sokolović D, Radović J, Tomić Z (2011b): Perennial forage grasses, from breeding to healthy ruminant feed. $3^{\text {rd }}$ International Congress "New Perspectives and Challenges of Sustainable Livestock production", 5-7 October, Beograd, Biotechnology in Animal Husbandry, 27 (1): 599-614.

Sokolović D, Tomić Z, Radović J, Lugić Z, Babić S, Simić A, Jevtić G (2012a): Broadening and evaluation of perennial forage crops autochthonous populations collection in Serbia. Book of abstracts of the 24th General Meeting of the European Grassland Federation, 3-7 June, Lublin, Poland, 32.

Sokolović D, Babić S, Radović J, Milenković J, Lugić Z, Anđelković S, Vasić T (2012b): Genetic variations of root characteristics and deep root production in perennial ryegrass cultivars contrasting in field persistency, Ch 36, 275-280. In: S. Barth and D. Milbourne (eds.) Breeding Strategies for Sustainable Forage and Turf Grass Improvement, Springer.

Statistical Office of the Republic of Serbia 
(2009): Statistical Yearbook of Serbia Belgrade.

Stevanović V, Vasić V, Regener S (2000): Biološka raznovrsnost SR Jugoslavijestanje, ugroženost, politika očuvanja. Savezno Ministarstvo za razvoj, nauku i životnu sredinu, Ecolibri-Biobet, Beograd

Tomić Z, Sokolović D, Radović J, Lugić $Z$ (2010): Genetic resources in Serbia, main aspect on forages. XII International Symposium on Forage
Crops of Republic of Serbia, 26-28 May, Kruševac-Serbia, Biotechnology in Animal Husbandry, 26 (Spec. issue) (1): 115-132.

Vučković S, Simić A, Đorđević N, Živković D, Erić P, Ćupina B, Stojanović I, PetrovićTošković S (2007): Uticaj đubrenja na prinos livade tipa Agrostietum vulgaris u Zapadnoj Srbiji. Zbornik radova Instituta za ratarstvo i povrtarstvo, Novi Sad, 44: 355-360. 


\title{
GENETIČKI RESURSI VIŠEGODIŠNJIH KRMNIH TRAVA U SRBIJI: TRENUTNO STANJE, PROŠIRENJE I EVALUACIJA \\ Dejan Sokolović, Snežana Babić, Jasmina Radović, Zoran Lugić, Aleksandar Simić, Vladimir Zornić, Mirjana Petrović
}

\begin{abstract}
Sažetak
Zahvaljujući svojoj geografskoj poziciji, klimi i reljefu, Srbija po broju biljnih vrsta i veličini teritorije (indeks biodiverziteta 0,72 ), predstavlja jedan od 158 svetskih centara biodiverziteta. Prirodne livade i pašnjaci zauzimaju značajne površine u Srbiji, veoma su bogate krmnim travnim vrstama i predstavljaju važan izvor germplazme za proces oplemenjivanja. Ovi ekosistemi predstavljaju osnovu za održivu stočarsku proizvodnju, pa iako se relativno male površine intenzivno koriste, javlja se potreba za očuvanjem postojećih, izuzetno bogatih, genetičkih resursa. Familija Poaceae je zastupljena u flori Srbije sa 70 rodova, a među njima, sa aspekta proizvodnje kvalitetne stočne hrane, najvažnije su vrste rodova Festuca, Lolium, Dactylis, Phleum, Bromus, Arrhenatherum, Poa i Agrostis. Veliki broj vrsta navedenih rodova je uključen u proces oplemenjivanja, a početni material za brojne registrovane sorte su bile uglavnom autohtone populacije, koje se odlikuju visokom varijabilnošću za mnoge osobine. Prikupljanje novih uzoraka, koji su tolerantni na lokalne eko-geografske uslove i njihovo uključivanje u biljnu banku gena, je od velikog značaja za dalje iskorišćavanje u različitim oplemenjivačkim programima, pa je stalno proširenje postojeće kolekcije krmnih trava permanentna aktivnost oplemenjivača u Srbiji. Prirodne populacije imaju visoku varijabilnost i veoma često zadovoljavajuće komponente prinosa u odnosu na postojeće sorte, što ih nakon karakterizacije i evaluacije važnih fenoloških, morfoloških i agronomskih osobina, preporučuje za direktno uključivanje u process selekcije. U ovom radu su predstavljeni genetički resursi krmnih trava, njihova divergentnost i potencijal, stanje u banci gena, kao i mogućnost kreiranja novih sorti.
\end{abstract}

Ključne reči: krmne trave, ex situ kolekcija, populacije, karakterizacija, evaluacija, varijabilnost

Primljen: 16.08.2017.

Prihvaćen: 25.08.2017. 